\title{
HYPOXIC STRESS, HEPATOCYTES AND CACO-2 VIABILITY AND SUSCEPTIBILITY TO Shigella flexneri INVASION
}

\author{
Camila Bárbara Cantalupo LIMA(1), Sânia Alves dos SANTOS(1) \& Dahir Ramos de ANDRADE JÚNIOR(1)
}

\begin{abstract}
SUMMARY
Inflammation due to Shigella flexneri can cause damage to the colonic mucosa and cell death by necrosis and apoptosis. This bacteria can reach the bloodstream in this way, and the liver through portal veins. Hypoxia is a condition present in many human diseases, and it may induce bacterial translocation from intestinal lumen. We studied the ability of $S$. flexneri to invade rat hepatocytes and Caco-2 cells both in normoxic and hypoxic microenvironments, as well as morphological and physiological alterations in these cells after infection under hypoxia. We used the primary culture of rat hepatocytes as a model of study. We analyzed the following parameters in normoxic and hypoxic conditions: morphology, cell viability, bacterial recovery and lactate dehydrogenase (LDH) released. The results showed that there were fewer bacteria within the Caco-2 cells than in hepatocytes in normoxic and hypoxic conditions. We observed that the higher the multiplicity of infection (MOI) the greater the bacterial recovery in hepatocytes. The hypoxic condition decreased the bacterial recovery in hepatocytes. The cytotoxicity evaluated by LDH released by cells was significantly higher in cells submitted to hypoxia than normoxia. Caco- 2 cells in normoxia released $63 \%$ more LDH than hepatocytes. LDH increased $164 \%$ when hepatocytes were submitted to hypoxia and just $21 \%$ when Caco- 2 cells were in the same condition. The apoptosis evaluated by Tunel was significantly higher in cells submitted to hypoxia than normoxia. When comparing hypoxic cells, we obtained more apoptotic hepatocytes than apoptotic Caco- 2 cells. Concluding our results contribute to a better knowledge of interactions between studied cells and Shigella flexneri. These data may be useful in the future to define strategies to combat this virulent pathogen.
\end{abstract}

KEYWORDS: Shigella flexneri; Hepatocytes; Caco-2 cells; Hypoxia; Apoptosis.

\section{INTRODUCTION}

Shigella flexneri (S. flexneri) is a gram-negative enterobacteria responsible for bacillary dysentery in humans. After oral ingestion, these bacteria reach the colon and may invade the intestinal barrier, mainly via translocation across M-cells of the Peyer's patches ${ }^{25}$. Then, bacterial translocation occurs through mesenteric lymph nodes or portal veins allowing bacterial access to liver ${ }^{16,24}$.

Many study models have been used for S. flexneri research as intragastric infection in guinea pigs and i.v. rabbit infection. These studies contributed to knowledge of Shigella sp. dissemination mechanisms as well as the recovery rates of these bacteria from the liver ${ }^{2,7}$.

Inflammatory processes present in atherosclerotic disease, dermal wounds, cardiovascular disorders, and microbial infections are implicated in the formation of tissue hypoxic areas ${ }^{3}$. Several processes can result in a hypoxic microenvironment, such as increased metabolic demand for leukocytes, microcirculation impairment and microorganism proliferation $^{15,20}$.
Intestinal hypoxia and reperfusion increase bacterial and endotoxine translocation and diminish their hepatic clearance ${ }^{14}$.

Furthermore, hypoxia can also be present in many liver diseases such as tumors, chronic hepatitis and cirrhosis, leading to morphological and functional alterations of the hepatocytes ${ }^{4,21,22}$. Hepatitis after Shigella spp. infection has also been reported in humans, although we cannot exclude other causes of hepatitis in this study ${ }^{30}$.

Most of the research of $S$. flexneri enterocyte invasiveness in vitro was made in intestinal epithelial cells lineages like Caco- 2 or T84 ${ }^{8,34}$. The Caco- 2 cell line is a continuous line of heterogeneous human epithelial colorectal adenocarcinoma cells that can be invaded by intestinal bacteria, among them $S$. flexneri $i^{9,19}$. S. flexneri has the powerful type III secretion system used to penetrate nonphagocitic cell types as enterocytes and hepatocytes $^{5,10,19}$.

There is no animal model that fully mimics the pathogenesis of shigellosis in humans. Therefore, alternative systems have been applied to study shigellosis, like the murine pulmonary model after intranasal

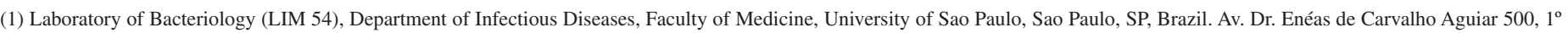
andar, sala 107, 05403-000 Sao Paulo, SP, Brazil. Tel/Fax:+55 11 3061-7029. E-mails: cantalupolima@gmail.com; saniasan@usp.br; dahira@uol.com.br

Correspondence to: Dahir Ramos de Andrade Júnior. E-mail: dahira@uol.com.br 


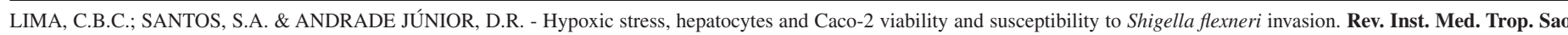
Paulo, 55(5): 341-6, 2013.

administration of bacteria and the intestinal infection of the newborn mice $^{18}$. The only model that mimics natural shigellosis in humans is the intragastric infection of Macacus rhesus. However, the scarcity of nonhuman primates and their cost creates difficulties in shigellosis studying ${ }^{18}$. For this reason, other study models were needed to advance the research in shigellosis. Our research group has then developed a experimental model of bacterial infection of primary rat hepatocytes cultured ${ }^{26}$.

This study has addressed the effect of hypoxia on hepatocytes and Caco-2 cells susceptibility to $S$. flexneri infection. The results showed that our model of cellular infection was effective to study the mechanisms underlying Shigella's infection.

\section{MATERIAL AND METHODS}

1. Primary culture of rat hepatocytes: Newborn female Wistar rats were obtained from the Central Bioterium of the Faculty of Medicine - University of São Paulo (USP), in a number of 15 rats per assay. The animals were anesthetized with $\mathrm{CO}_{2}$ before surgical procedures. The livers were excised using an aseptic technique under biological safety cabinet as described previously ${ }^{26}$. The material was then transferred to 24 -well plates (Corning) previously covered with $50 \mu \mathrm{g} / \mathrm{mL}$ laminin (Sigma). Cells were incubated with Williams' E medium (Sigma) containing 2\% of fetal calf serum (Cultilab) enriched with several supplements as described previously ${ }^{26}$. Cells were placed in an incubator at $37^{\circ} \mathrm{C}$ in a humidified atmosphere of $5 \% \mathrm{CO}_{2}$ in air, and used after 7-8 days of culture. The study design was approved by the Research Ethics Committee of the institution.

2. Culture of Caco-2 cells line: Caco- 2 cell line was kindly provided by Dr. André Zonetti de Arruda Leite from Gastroenterology Laboratory (LIM-07) of the Faculty of Medicine - University of São Paulo (USP). Cells were incubated with DMEM medium (Sigma) containing $20 \%$ of fetal bovine serum (Cultilab). After this, Caco-2 cells were placed in an incubator at $37^{\circ} \mathrm{C}$ in a humidified atmosphere of $5 \% \mathrm{CO}_{2}$ in air and used after 7-8 days of culture.

3. Hypoxic conditions: Both hepatocytes and Caco-2 cells were cultured for 7-8 days. The experimental groups are referred to as hypoxia $(\mathrm{H})$ and normoxia $(\mathrm{N})$. Another two experimental groups were formed: "normoxia + infection" with cells cultured for 7-8 days and then infected with $S$. flexneri in multiplicity of infection (MOI) 5, 50 and 500, and "hypoxia + infection" with cells cultured for 7-8 days submitted to hypoxia for $24 \mathrm{~h}$ and then infected with $S$. flexneri in MOIs 5, 50 and 500. The normoxia group was placed in an incubator at $37{ }^{\circ} \mathrm{C}$. The hypoxia groups were placed into a gas-tight modular chamber (Billups-Rothenberg, Del Mar, CA) for 24h. The chamber was gassed for $30 \mathrm{~min}$ at a flow rate of 10 liters/min using certified gases containing $\mathrm{N}_{2}$ (White Martins - São Paulo, Brazil) and placed in an incubator at $37^{\circ} \mathrm{C}$. The oxygen concentration in cell cultures under hypoxic was $<1 \%$, measured at a gas meter apparatus (Radiometer ABL800 Flex, Denmark).

4. Bacterial invasion and recovery assay: Shigella flexneri 2 a strain (NCTC 9729) was grown in Brain Heart Infusion medium (Difco) for $16 \mathrm{~h}$ at $37^{\circ} \mathrm{C}$. Cells cultured in 24-well plates (Corning) at $1 \times 10^{5}$ cells $/ \mathrm{mL}$ were infected with $S$. flexneri at MOIs 5, 50 and 500, one h for hepatocytes and three $\mathrm{h}$ for Caco- 2 cells, at $37^{\circ} \mathrm{C}$ with previous centrifugation of cells/bacteria at $1000 \mathrm{rpm}$ for $10 \mathrm{~min}$. Cells were incubated with
$50 \mu \mathrm{g} / \mathrm{mL}$ gentamicin (Sigma) for one $\mathrm{h}$ at $37^{\circ} \mathrm{C}$, followed by PBS washing and later lyses with Triton X-100 (Sigma) 1\% during five min for intracellular bacteria recovery. The number of viable intracellular bacteria was determined by plating serial dilutions of the cells lysates on blood agar and CFU counting. The number obtained was divided by the well's area of the cell culture.

5. Hematoxylin-eosin staining: Cells monolayers grown on glass coverslips were washed three times with PBS, fixed with methanol (Merck) for two min and then hydrated in a graded series of alcohol (Merck) for five min. Subsequently, the coverslips were stained with hematoxylin (Sigma) for $20 \mathrm{~min}$ and then washed with tap water. After this they were stained with eosin (Sigma) for $20 \mathrm{~min}$, washed with distilled water and dehydrated in a graded series of alcohol, immersed in xylenol (Merck) and mounted in Canada balsam (Vetec). Images were analyzed in an optical microscope with digital image capture system (Leica) ${ }^{26}$.

6. Viability assay: Hepatocytes and Caco-2 cells cultures in normoxic and hypoxic conditions were washed three times with PBS, and detached from wells using Trypsin-EDTA solution. The cells' suspensions were centrifuged at $1500 \mathrm{rpm}$ for five minutes and the supernatants were removed. The cell pellets were resuspended in $1 \mathrm{~mL}$ PBS. After this the cells were stained with Trypan blue and counted in a Neubauer chamber.

7. Detection of the LDH released: Detection of LDH (normoxic and hypoxic cells) released was made by specific colorimetric kit (Sigma). The assays were performed in two steps: 1) without cell lysis to measure the $\mathrm{LDH}$ released; 2) with cell lysis to measure the total $\mathrm{LDH}$ (released + intracellular). The steps were carried out in the following sequence:

A) Step 1: The cell cultures in 24-well plates (Corning) were centrifuged at $1100 \mathrm{rpm}$ for four minutes and then an aliquot of $50 \mu \mathrm{L}$ from each well was transferred to 96-well plates.

B) Step 2: We added 1/10 lysis buffer in each well of 24-well plates (kit), followed by incubation at $37^{\circ} \mathrm{C}$ for 45 minutes. After this, the plate was centrifuged at $1100 \mathrm{rpm}$ for four minutes and then an aliquot of 50 $\mu \mathrm{L}$ from each well was transferred in 96-well plates.

The enzyme dosage was performed to both types of samples (LDH released and LDH total). We added $100 \mu \mathrm{L}$ of solution in each well containing equal volume of substrate, cofactor and dye. The plate was then incubated for 30 minutes at room temperature protected from light. The reaction was blocked by adding $15 \mu \mathrm{L}$ of $\mathrm{HCl} 1 \mathrm{M}$ to each well, then readings were taken with a spectrophotometer at the wavelengths of 490 $\mathrm{nm}$ and $690 \mathrm{~nm}$. The results were obtained by subtracting the result of the wavelength of $490 \mathrm{~nm}$ wavelength from that of the wavelength of $690 \mathrm{~nm}$; this was carried out using specific software (Soft max Pro).

Data analysis were performed by calculating the percentage of cytotoxicity according to the formula:

$$
\% \text { Cytotoxicity }=100 \times \frac{\text { LDH released }}{\text { LDH total }}
$$

LDH released: absorbance result of non-lysed cells. LDH total: absorbance result of cell lysates. 
8. Apoptosis detection: Detection of fragmented DNA (TUNEL technique) was assayed using Fragment End Labeling Kit (FragEL kit; Calbiochem, Oncogene Research Products, Cambridge, MA, USA), in accordance with the manufacturer's instructions. Hepatocytes and Caco-2 cells were cultured in glass cover slips and a total of 10 successive fields were counted in fluorescence microscope (Leica).

9. Statistical analysis: All the experiments were repeated at least ten times, and the Kruskal-Wallis test along with the Student Newman Keuls post-hoc test were used for statistical analysis. The alpha risk was considered statistically significant when $p \leq 0.05$.

\section{RESULTS}

1. Cell viability: The cellular viability data after invasion by $S$. flexneri can be seen in Figure 1. Caco-2 cells submitted to hypoxia presented significant difference when compared to Caco-2 cells in normoxia only at MOI 500. In all other experimental conditions no significant differences were observed.

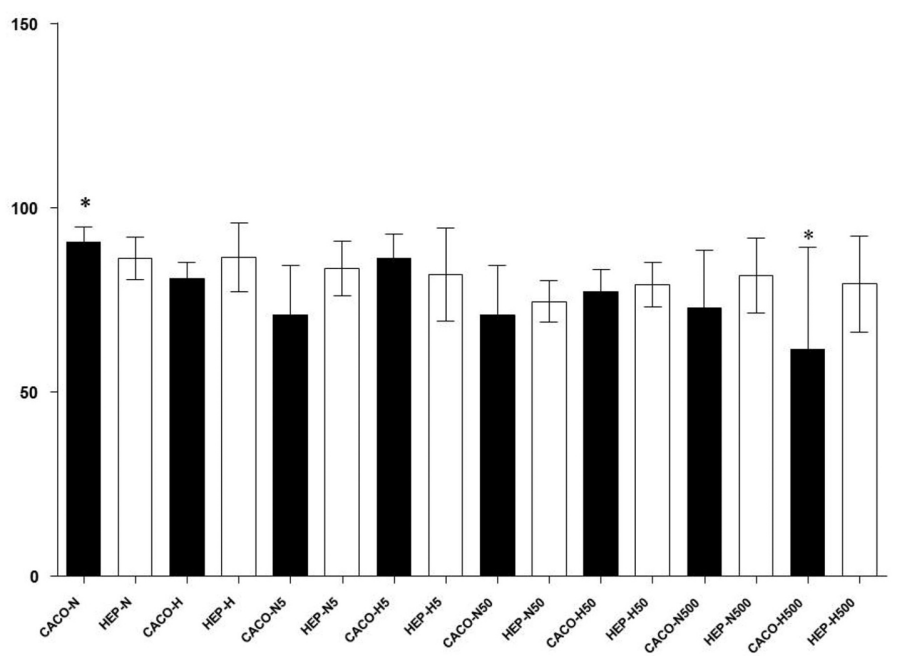

Fig. 1 - Evaluation of Hepatocytes (HEP) and Caco-2 cells (CACO) viability under hypoxia (H) or normoxia $(\mathrm{N})$ submitted to infection by $S$. flexneri in MOIs 5, 50 and 500 . $(*=p \leq 0.001)$.

2. Oxygen consumption: We found that Caco-2 cells consumed oxygen in a quantity significantly greater than hepatocytes in normoxic conditions (Fig. 2). In contrast, hepatocytes consumed more oxygen than Caco-2 cells under hypoxia. Apparently Caco-2 cells were able to drastically reduce their intake of oxygen at nearly undetectable levels under hypoxia.

3. Bacterial recovery: The minimum time required for bacterial invasion was one hour for hepatocytes and three hours for Caco- 2 cells. The results showed that bacterial invasion was lower in Caco-2 cells than in hepatocytes in both normoxic and hypoxic conditions (Fig. 3).

We observed that the higher the MOI the greater the bacterial recovery's rate in the hepatocytes. The hypoxic condition reduced the bacterial recovery in comparison to normoxic condition in these cells. We also found that there was no significant difference among Caco-2 groups (normoxia and hypoxia).

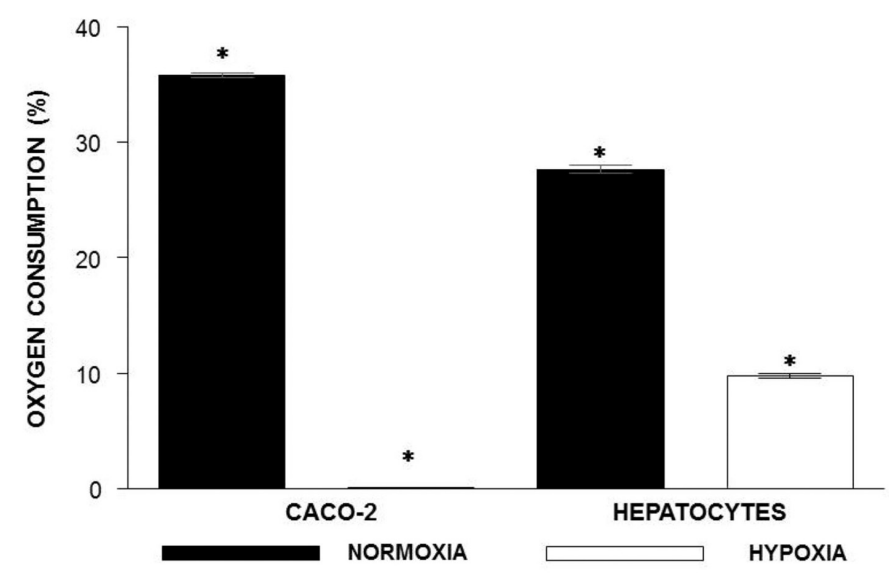

Fig. 2 - Oxygen consumption of hepatocytes and Caco-2 under normoxia and hypoxia conditions $(*=p \leq 0.001)$.

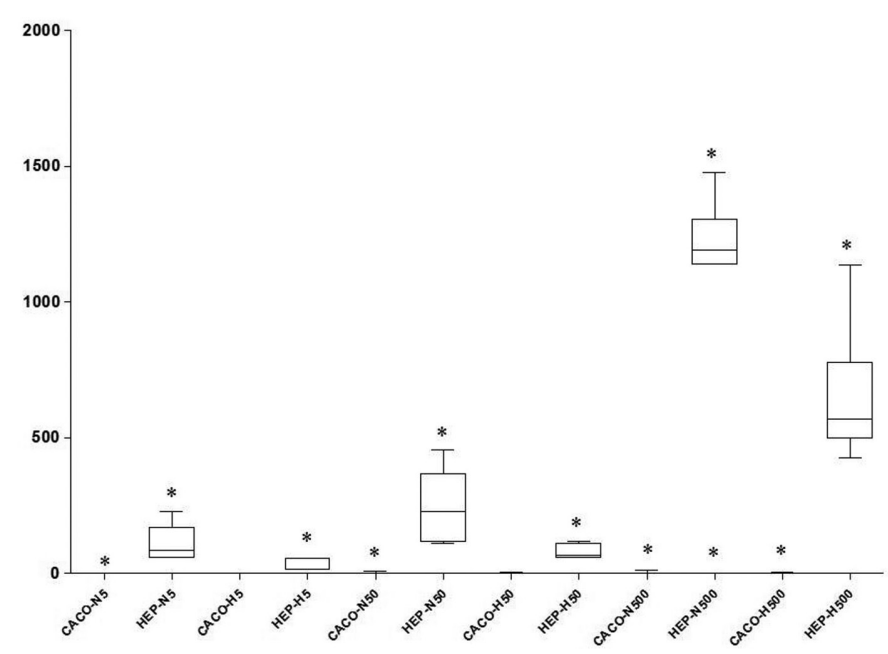

Fig. 3 - Bacterial recovery from Caco-2 cells (CACO) and hepatocytes (HEP) under normoxia (N) or hypoxia $(\mathrm{H})$ submitted to infection by $S$. flexneri in MOIs 5,50 and $500(*=p \leq 0.001)$ (CACO-N5/50/500 versus HEP-N5/50/500, CACO-H500 versus HEP-H500; HEP-H5 versus H500, H5 versus N5, H50 versus H500, H50 versus N50, N5 versus N500, N5 versus N50, N50 versus N500, H500 versus N500).

4. Evaluation of cytotoxicity: Percentage of cytotoxicity can be seen in Figure 4. The rates of LDH released in normoxic condition were higher in Caco-2 cells, while in hypoxic condition the hepatocytes produced the highest rates of LDH. In both cell types studied there was higher LDH released in hypoxia condition than in normoxia. There were significant differences in all comparisons.

5. Apoptosis quantification: Hypoxic hepatocytes and Caco-2 cells groups had higher apoptosis rates when compared to normoxic control groups. There was a significant difference in apoptosis rate among normoxic and hypoxic groups and Caco-2 cells and hepatocytes both hypoxic (Fig. 6).

6. Morphological analysis: Normoxic hepatocyte cultures presented cells arranged in monolayer with wide cell junctions, while cells submitted to $24 \mathrm{~h}$ hypoxia showed piknotic nuclei as well as monolayer ruptures (Fig. 5). Caco-2 cells cultured in normoxic condition presented 


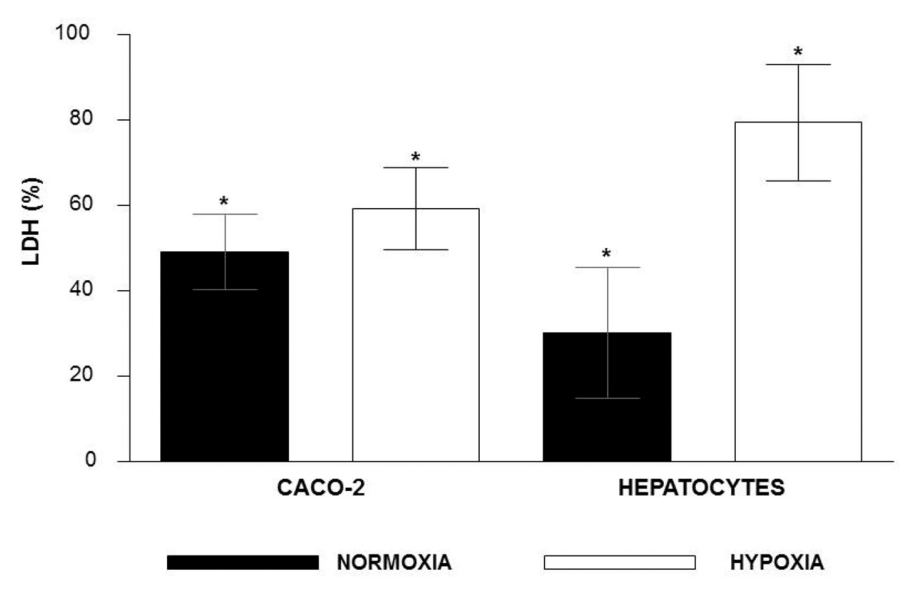

Fig. 4 - Percentage of hepatocytes and Caco-2 cells cytotoxicity under hypoxic and normoxic atmosphere conditions according the release of lactate dehydrogenase from cells $(*=p \leq 0.001)$.
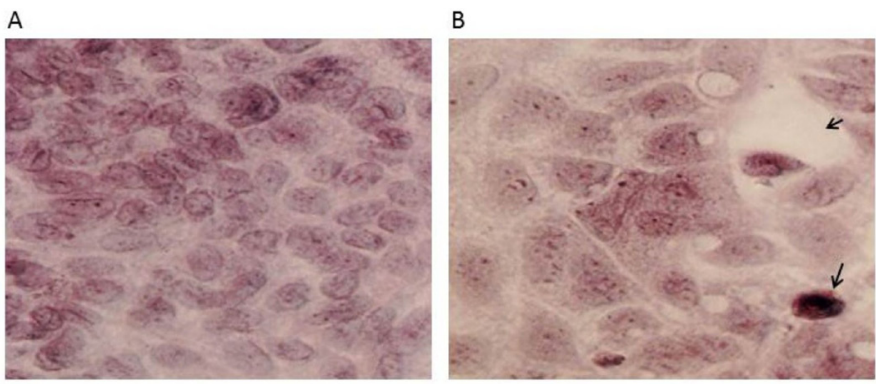

C

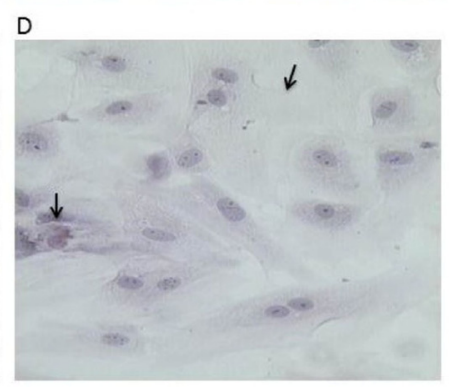

Fig. 5 - Caco-2 cells in Normoxia (A) and Hypoxia (B); Hepatocytes in Normoxia (C) and Hypoxia (D). The arrows indicate piknotic nuclei and monolayer disruption (X400).

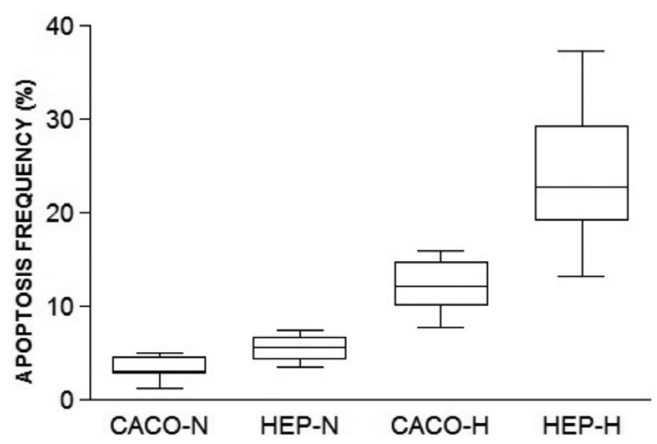

Fig. 6 - Percentage of apoptotic cells cultured under normoxic or hypoxic conditions. ( $p<$ 0.005 , all comparisons except Caco- $\mathrm{N} \times$ Hep-N). a confluent monolayer. These cells were larger than hepatocytes and they had close contact with each other. When submitted to hypoxia, Caco-2 monolayer showed ruptures as well as piknotic nuclei.

\section{DISCUSSION}

Hepatocytes and Caco-2 cells were able to maintain their viability (ranging between 74-87\%) in order to allow the experimental assessment. Although hypoxia reduces cell proliferation and increases cell damage ${ }^{33}$, we observed that hypoxia alone doesn't decrease cell viability significantly. Only in the Caco-2 cells group infected at MOI 500 there was a significant decrease in the Caco-2's viability in hypoxia condition compared to normoxia. There was no difference between hepatocytes and Caco-2 viabilities in all other groups. These results suggest that the presence of bacteria in different concentrations did not bring significant changes in hepatocytes and Caco-2 viability.

$\mathrm{O}_{2}$ homeostasis has evolved into a complex system to regulate $\mathrm{O}_{2}$ delivery ${ }^{27}$. In our study we observed that Caco- 2 cells consumed more oxygen than hepatocytes in normoxic condition (Fig. 3). In contrast hepatocytes consumed more oxygen than Caco- 2 cells under hypoxia. These results suggest that Caco- 2 cells are more adapted to hypoxic environments. We speculate that their tumoral origin is the explanation for this phenomenon. The selection of hypoxia-resistant cells usually occurs in tumor tissues ${ }^{28}$.

S. flexneri required less time to invade hepatocytes (one hour) than Caco- 2 cells (three hours). This period was lower when compared to other intestinal tumoral lineages with similar bacterial recovery rate ${ }^{18}$. We also observed that $S$. flexneri were less able to invade hepatocytes under hypoxic conditions. This result is similar to that obtained by other authors with other pathogens and cells types ${ }^{6,23,29}$. Hypoxia can modify gene expression, intra and extracellular $\mathrm{pH}$ as well as membrane receptors ${ }^{1,12,32}$. These changes may disturb the bacterial invasion both in hepatocytes and Caco-2.

The results about bacterial recovery from cells studied showed that there were fewer bacteria within the Caco- 2 cells than in hepatocytes on normoxia and hypoxia conditions (Fig. 4). There were significant differences in bacterial recovery rate among hepatocytes groups, as well as among hepatocytes and Caco-2 groups. We also observed that the higher the MOI the greater the bacterial recovery from hepatocytes. The hypoxic condition decreased the bacterial recovery in hepatocytes. Structural alterations of the cells under hypoxia probably obstruct the entry of bacteria. There is evidence that Shigella sp undergoes adjustments against hypoxia. MARTEYN et al. ${ }^{17}$ showed that $S$. flexneri have the ability to detect oxygen varying tensions, which allows T3SS activation enhancing invasion and virulence of this bacteria. This bacterial adaptation could not overcome the structural alteration of the cells.

Cytotoxicity evaluated by LDH released was significantly higher in cells submitted to hypoxia than normoxia (Fig. 4). These results are in agreement with other studies with human hepatocytes, cardiomyocytes and mesenchymal cells ${ }^{31}$. We also observed that Caco- 2 cells in normoxia produced $63 \%$ more LDH than hepatocytes. On the other hand hepatocytes produced $34 \%$ more LDH than Caco- 2 cells under hypoxia. LDH increased $164 \%$ when hepatocytes were submitted to hypoxia and just $21 \%$ when Caco- 2 cells were in the same condition. The percentage of LDH released is a cytotoxic index widely used in studies of hepatocyte 
injury, primarily reflecting membrane integrity ${ }^{13}$. In agreement with the results of LDH released, the morphological analysis also showed greater injury to hepatocytes under hypoxia compared to Caco- 2 cells (Fig. 5). These results agree to evaluation of apoptosis by Tunel, where there are more hypoxic apoptotic hepatocytes than hypoxic apoptotic Caco- 2 cells. We speculated that hypoxia produced more changes in the cell membrane of epithelial origin (hepatocytes) than those of tumoral origin (Caco-2). Besides this, hypoxia is a common condition when a tumor expands and it may induce the expression of hypoxia-inducible factor (HIF), a transcription factor that initiates a range of pro-survival mechanisms ${ }^{11}$. It is possible that HIF was more expressed in Caco- 2 cells than in the hepatocytes due to their tumoral origin. This phenomenon would contribute to lower injury Caco- 2 under hypoxia. Hepatocytes submitted to hypoxia had increased apoptosis rates compared to normoxic cells (Fig. 4).

In brief, our results contribute to a better knowledge of interactions between studied cells and S. flexneri. Hypoxia appears to influence significantly the bacterial cell invasiveness. The differences observed between these two cellular model systems could be due to us having compared primary cells (rat hepatocytes) and tumoral cell lines (Caco-2). Furthermore, our results suggest that tumoral cells are more resistant to infection and hypoxia than primary cells. More details on this complex interaction await further studies. This knowledge will be important to improve strategies to combat this virulent pathogen in the future.

\section{RESUMO}

\section{Stress hipóxico, viabilidade e susceptibilidade de hepatócitos e células Caco-2 à invasão por Shigella flexneri}

A inflamação causada por Shigella flexneri pode causar danos à mucosa do cólon e morte celular por necrose e apoptose. Esta bactéria pode atingir a corrente sanguínea por esta via e o fígado através da veia porta. A hipóxia é uma condição presente em muitas doenças humanas, podendo induzir a translocação bacteriana a partir do lúmen intestinal. Nós estudamos a capacidade de S. flexneri invadir hepatócitos de rato e células Caco-2 nos microambientes de normóxia e hipóxia, bem como as alterações morfológicas e fisiológicas dessas células após a infecção sob hipóxia. Utilizamos a cultura primária de hepatócitos de ratos como modelo de estudo. Nós analisamos os seguintes parâmetros em condições de normóxia e hipóxia: morfologia, viabilidade celular, recuperação bacteriana e liberação de lactato desidrogenase (LDH). Os resultados mostraram menor quantidade de bactérias dentro das células Caco-2 do que em hepatócitos em condições de normóxia e hipóxia. Nós observamos que quanto maior foi a multiplicidade de infecção (MOI), maior também foi a recuperação bacteriana em hepatócitos. A condição hipóxica foi capaz de diminuir a recuperação de bactérias dos hepatócitos. A citotoxicidade avaliada pela liberação de LDH foi significativamente maior em células submetidas à hipóxia do que normóxia. As células Caco-2 em normóxia produziram $63 \%$ mais $\mathrm{LDH}$ do que os hepatócitos. $\mathrm{O}$ LDH aumentou $164 \%$ quando os hepatócitos foram submetidos à hipoxia e apenas $21 \%$ quando as células Caco-2 estavam na mesma condição. A apoptose avaliada por TUNEL foi significativamente maior em células submetidas à hipóxia que normóxia. Quando comparamos células hipóxicas houve mais apoptose entre hepatócitos do que nas células Caco-2. Concluindo, nossos resultados contribuem para um melhor conhecimento das interações entre as células estudadas e $S$. flexneri. Estes dados podem ser úteis no futuro, para definir estratégias de combate a este patógeno virulento.

\section{ACKNOWLEDGEMENTS}

This work was supported by the "Fundação de Amparo à Pesquisa do Estado de São Paulo" (FAPESP, Foundation for the Support of Research in the state of São Paulo).

\section{REFERENCES}

1. Berger ML, Reynolds RC, Hagler HK, Bellotto D, Parsons D, Mulligan KJ, et al. Anoxic hepatocyte injury: role of reversible changes in elemental content and distribution. Hepatology. 1989;9:219-28.

2. Bernardini ML, Arondel J, Martini I, Aidara A, Sansonetti PJ. Parameters underlying successful protection with live attenuated mutants in experimental shigellosis. Infect Immun. 2001;69:1072-83.

3. Bosseto MC, Palma PV, Covas DT, Giorgio S. Hypoxia modulates phenotype, inflammatory response, and leishmanial infection of human dendritic cells. APMIS 2010;118:108-14.

4. Bottaro DP, Liotta LA. Cancer: out of air is not out of action. Nature. 2003;423:593-5.

5. Bukholm G, Modalsli K, Degré M. Effect of measles-virus infection and interferon treatment on invasiveness of Shigella flexneri in HEp2-cell cultures. J Med Microbiol. 1986;22:335-41.

6. Colhone MC, Arrais-Silva WW, Picoli C, Giorgio S. Effect of hypoxia on macrophage infection by Leishmania amazonensis. J Parasitol. 2004;90:510-5.

7. Etheridge ME, Hoque AT, Sack DA. Pathologic study of a rabbit model for shigellosis. Lab Anim Sci. 1996;46:61-6.

8. Flamant M, Aubert P, Rolli-Derkinderen M, Bourreille A, Neunlist MR, Mahé MM, et al. Enteric glia protect against Shigella flexneri invasion in intestinal epithelial cells: a role for S-nitrosoglutathione. Gut. 2011;60:473-84.

9. Fogh J, Trempe G. New human tumor cell lines. In: Fogh J, ed. Human tumor cells in vitro. New York: Plenum; 1975. p. 115-41.

10. Galan JE, Collmer A. Type III secretion machines: bacterial devices for protein delivery into host cells. Science. 1999;284:1322-8.

11. Greer SN, Metcalf JL, Wang Y, Ohh M. Review. The updated biology of hypoxia-inducible factor. EMBO J. 2012;31:2448-60.

12. Herman B, Gores GJ, Nieminen AL, Kawanishi T, Harman A, Lemasters JJ. Calcium and $\mathrm{pH}$ in anoxic and toxic injury. Crit Rev Toxicol. 1990;21:127-48.

13. Jauregui HO, Hayner NT, Driscoll JL, Williams-Holland R, Lipsky MH, Galletti PM. Trypan blue dye uptake and lactate dehydrogenase in adult rat hepatocytes freshly isolated cells, cell suspensions, and primary monolayer cultures. In Vitro. 1981;17:1100-10.

14. Kondo S, Wang D, Mayumi T, Klein AS, Bulkley GB. Effect of hemorrhagic shock and resuscitation upon hepatic phagocytic clearance and killing of circulating microorganisms. Shock. 1996;5:106-11.

15. Lewis JS, Lee JA, Underwood JC, Harris AL, Lewis CE. Macrophage responses to hypoxia: relevance to disease mechanisms. J Leukoc Biol. 1999;66:889-900.

16. Macutkiewicz C, Carlson G, Clark E, Dobrindt U, Roberts I, Warhurst G. Characterisation of Escherichia coli strains involved in transcytosis across gut epithelial cells exposed to metabolic and inflammatory stress. Microbes Infect. 2008;10:424-31. 
17. Marteyn B, West NP, Browning DF, Cole JA, Shaw JG, Palm F, et al. Modulation of Shigella virulence in response to available oxygen in vivo. Nature. 2010;465:355-8.

18. Martino MC, Rossi G, Tattoli I, Martini I, Chiavolini D, Cortese G, et al. Intravenous infection of virulent shigellae causes fulminant hepatitis in mice. Cell Microbiol. 2005; 7:115-27.

19. Mounier J, Vasselon T, Hellio R, Lesourd M, Sansonetti PJ. Shigella flexneri enters human colonic Caco-2 epithelial cells through the basolateral pole. Infect Immun. 1992;60:237-48.

20. Murdoch C, Muthana M, Lewis CE. Hypoxia regulates macrophage functions in inflammation. J Immunol. 2005;175:6257-63.

21. Raurich JM, Llompart-Pou JA, Ferreruela M, Colomar A, Molina M, Royo C, et al. Hypoxic hepatitis in critically ill patients: incidence, etiology and risk factors for mortality. J Anesth. 2011;25:50-6.

22. Rosmorduc O, Wendum D, Corpechot C, Galy B, Sebbagh N, Raleigh J, et al. Hepatocellular hypoxia-induced vascular endothelial growth factor expression and angiogenesis in experimental biliary cirrhosis. Am J Pathol. 1999;155:1065-73.

23. Roth A, König P, van Zandbergenc G, Klinger M, Hellwig-Bürgel T, Däubener W, et al. Hypoxia abrogates antichlamydial properties of IFN-gamma in human fallopian tube cells in vitro and ex vivo. Proc Natl Acad Sci USA. 2010;107:19502-7.

24. Sandler NG, Koh C, Roque A, Eccleston JL, Siegel RB, Demino M, et al. Host response to translocated microbial products predicts outcomes of patients with $\mathrm{HBV}$ or $\mathrm{HCV}$ infection. Gastroenterology. 2011;141:1220-30.

25. Sansonetti PJ. Microbes and microbial toxins: paradigms for microbial-mucosal interactions. III. Shigellosis: from symptoms to molecular pathogenesis. Am J Physiol Gastrointest Liver Physiol. 2001;280:319-23.

26. Santos SA dos, Andrade Júnior DR de, Andrade DR de. TNF-alpha production and apoptosis in hepatocytes after Listeria monocytogenes and Salmonella Typhimurium invasion. Rev Inst Med Trop Sao Paulo. 2011;53:107-12.
27. Shimoda LA, Polak J. Hypoxia. 4. Hypoxia and ion channel function. Am J Physiol Cell Physiol. 2011;300:C951-C67.

28. Shipp C, Derhovanessian E, Pawelec G. Effect of culture at low oxygen tension on the expression of heat shock proteins in a panel of melanoma cell lines. PLoS One. 2012;7:e37475.

29. Spear W, Chan D, Coppens I, Johnson RS, Giaccia A, Blader IJ. The host cell transcription factor hypoxia-inducible factor 1 is required forToxoplasma gondii growth and survival at physiological oxygen levels. Cell Microbiol. 2006;8:339-52.

30. Stern MS, Gitnick GL. Shigella hepatitis. JAMA. 1976;235:2628.

31. Tüzüner E, Liu L, Shimada M, Yilmaz E, Glanemann M, Settmacher U, et al. Heme oxygenase-1 protects human hepatocytes in vitro against warm and cold hypoxia. J Hepatol. 2004;41:764-72.

32. Wenger RH. Cellular adaptation to hypoxia: $\mathrm{O}_{2}$-sensing protein hydroxylases, hypoxiainducible transcription factors, and $\mathrm{O}_{2}$-regulated gene expression. FASEB J. 2002;16:1151-62.

33. Zitta K, Meybohm P, Bein B, Huang Y, Heinrich C, Scholz J, et al. Salicylic acid induces apoptosis in colon carcinoma cells grown in-vitro: influence of oxygen and salicylic acid concentration. Exp Cell Res. 2012;318:828-34.

34. Zurawski DV, Mumy KL, Faherty CS, McCormick BA, Maurelli AT. Shigella flexner type III secretion system effectors $\mathrm{OspB}$ and $\mathrm{OspF}$ target the nucleus to downregulate the host inflammatory response via interactions with retinoblastoma protein. $\mathrm{Mol}$ Microbiol. 2009; 71:350-68.

Received: 4 September 2012

Accepted: 6 March 2013 